\title{
Anaerobic degradation of tetrachloromethane by Acetobacterium woodii: separation of dechlorinative activities in cell extracts and roles for vitamin $B_{12}$ and other factors
}

\author{
Susanna A. Stromeyer, Karin Stumpf, ${ }^{1}$ Alasdair M. Cook \& Thomas Leisinger
}

Microbiology Institute, Swiss Federal Institute of Technology, CH-8092 Zürich, Switzerland; ${ }^{1}$ Present address: EMPA, CH-8600 Dübendorf, Switzerland

Key words: tetrachloromethane, dechlorination by non-enzymic catalysts; chlorinated aliphatic solvents, anaerobic biotransformation; dechlorination by reduced corrinoids

\begin{abstract}
The transformations of ${ }^{14} \mathrm{CCl}_{4}$ by whole cells of Acetobacterium woodii suspended in phosphate buffer containing reducing agents, and by the cobalt corrinoid aquocobalamin in the same solution, were compared. Each catalyst transformed ${ }^{14} \mathrm{CCl}_{4}$ not only to reduced products $\left(\mathrm{CHCl}_{3}\right.$ and $\left.\mathrm{CH}_{2} \mathrm{Cl}_{2}\right)$ but also to $\mathrm{CO}$ and $\mathrm{CO}_{2}$ as well as non-volatile products. The mass balance for radioactive carbon was complete in each case. Thus, the reactions of the pure cobalt corrinoid resemble the reactions in vivo. The proton in $\mathrm{CHCl}_{3}$, formed from $\mathrm{CCl}_{4}$ by $A$. woodii, was derived from water. Extracts of $A$. woodii were fractionated into large and small molecules, and each of the two fractions was separated chromatographically. Fractions of proteins demonstrated poor correlation between content of the corrinoid vitamin $B_{12}$ and rates of transformation of $\mathrm{CCl}_{4}$. The correlation was somewhat improved if the fractions were autoclaved, but dechlorination in the absence of vitamin $B_{12}$ was observed. Separation of the small molecules yielded only one fraction containing vitamin $\mathbf{B}_{12}$, and this fraction catalyzed dechlorination, whereas several other fractions were able to dechlorinate $\mathrm{CCl}_{4}$ in the absence of vitamin $\mathrm{B}_{12}$. We presume there to be unrecognized dechlorinative factors in anaerobic bacteria.
\end{abstract}

Abbreviations: GC - gas chromatograph(y); GC-MS (or -TCD or -FID) - GC coupled to a mass spectrometer (or a thermal conductivity detector or a flame ionization detector); HPLC - high pressure liquid chromatograph(y); FPLC - high pressure protein chromatograph(y)

\section{Introduction}

Transformations of halogenated aliphatic hydrocarbons in strictly anaerobic bacteria are well known (Cook et al. 1988; Vogel et al. 1987; Wackett 1991), but the biochemistry of the reactions in vivo is largely unclear. Only dichloromethane and chloromethane have been shown to be carbon and energy sources for anaerobic growth (Freedman \& Gossett 1991; Stromeyer et al. 1991; Traunecker et al. 1991), and it is unclear whether the same mechanisms of dechlorination are used during growth and biotransformations. The known biotransformation reactions are several variants of reductive (Cook et al. 1988; Gälli \& McCarty 1989; Vogel et al. 1987), substitutive (Egli et al. 1988, 1990) or oxidative 
(Egli et al. 1990) reactions. These biotransformations usually give complete mass balances for educt and products, which include water-soluble, nonvolatile material and $\mathrm{CO}_{2}$ (Egli et al. 1988, 1990; cf. Criddle et al. 1990a, b).

Pure cobalt, nickel or iron tetrapyrrole cofactors can catalyze reductive dechlorination of chlorinated aliphatic hydrocarbons (Klecka \& Gonsior 1984; Gantzer \& Wackett 1991; Krone et al. 1989a, b). However, these experiments usually result in incomplete mass balances for the chlorinated compound. These cofactors catalyze reductive dechlorination of $\mathrm{CCl}_{4}$, and, in one case (Krone et al. 1991), the formation of $\mathrm{CO}$ (but not $\mathrm{CO}_{2}$ ). The established reactions with pure tetrapyrrole cofactors thus do not adequately represent the biotransformations observed in vivo. The suggestion that flavins, as opposed to flavoproteins, also catalyze dechlorinative reactions under anaerobic conditions (Kuhn \& Suflita 1989; Criddle et al. 1990a) has not been examined in detail.

Acetobacterium woodii catalyzes the reductive dechlorination of $\mathrm{CCl}_{4}$ and its substitutive transformation to $\mathrm{CO}_{2}$; with $\mathrm{CHCl}_{3}$, these two reaction types and an oxidation step (to $\mathrm{CO}_{2}$ ) are known. These reactions are also observed in cell-free extracts and in autoclaved cells or extracts (Egli et al. $1988,1990)$. The organism does not contain coenzyme $\mathrm{F}_{430}$ or cytochromes (Dangel et al. 1987; Stupperich et al. 1988) so it presumably lacks both iron porphyrins and nickel porphyrins, whereas the presence of one cobalt corrinoid (vitamin $\mathrm{B}_{12}$ ) is well established (Stupperich et al. 1988). A. woodii is thus a suitable organism to test the hypothesis that vitamin $B_{12}$ alone is responsible for the dehalogenations observed in this bacterium.

\section{Materials and methods}

\section{Materials and apparatus}

The sources of chlorinated hydrocarbons, ${ }^{14} \mathrm{CCl}_{4}$ and $\mathrm{CH}_{4}$, Viton stoppers, scintillation fluid and general chemicals were described elsewhere (Egli et al. 1987, 1988, 1990). Aquocobalamin was from Fluka (Buchs, Switzerland) and $\mathrm{D}_{2} \mathrm{O}(98 \%)$ from the Paul Scherrer Institut (Villingen, Switzerland). The FPLC anion-exchange column (Mono $Q$, $100 \times 10 \mathrm{~mm}$ ) and PD-10 columns of Sephadex G-25 were obtained from Pharmacia, Uppsala, Sweden. HPLC was done on reversed-phase columns (Grossenbacher et al. 1986).

The anaerobic glovebox (Egli et al. 1989), HPLC, GC-TCD, liquid scintillation counter and spectrophotometer (Egli et al. 1988), GC-FID equipped with a methanizer (8700; Perkin Elmer, Beaconsfield, Bucks, UK), GC-MS (5890-5870, Hewlett-Packard, Avondale, PA) and atom absorption spectrophotometer equipped with a graphite tube atomizer (Spectra AA400/GTA-96; Varian, Palo Alto, CA) were commercially-available equipment. FPLC was done with LKB apparatus (Pharmacia/LKB) attached to a fraction collector (2110; Bio-Rad, Richmond, CA, USA) which could be passed into the glovebox, and which was adapted to allow collection of samples under anaerobic conditions. The gassing manifold was described by Kiener \& Leisinger (1983).

\section{Analyses}

Chlorinated hydrocarbons and methane were determined by GC-FID after separation on a Porapak P column (Scholtz et al. 1987). A fused silica capillary column was used for GC-MS. $\mathrm{CO}$ and $\mathrm{CO}_{2}$, produced in experiments initially devoid of $\mathrm{CO}_{2}$ and $\mathrm{H}_{2} \mathrm{~S}$, were determined as methane by GC-FID after separation on Carbosieve $B$ in apparatus equipped with a methanizer. Radiolabelled $\mathrm{CO}$ and $\mathrm{CO}_{2}$ were separated by GC-TCD, trapped, and quantified in a liquid scintillation counter (Egli et al. 1988); ${ }^{14} \mathrm{CO}_{2}$ was also quantified as described by Fuchs et al. (1980). Water-soluble, radioactive products from ${ }^{14} \mathrm{CCl}_{4}$ were assayed as that radioactivity remaining in aqueous solution after acidification (to $\mathrm{pH} 2.5$ with $1 \mathrm{M} \mathrm{H}_{2} \mathrm{SO}_{4}$ ) and extraction with one volume of hexane. Vitamin $B_{12}$ was determined in a radioimmunoassay (Magic No Boil $\mathrm{B}_{12^{-}}$ Folate; Ciba-Corning, Medfield, MS, USA). The metal ions cobalt, nickel and iron from biological samples were determined by atomic absorption spectrometry (Welz 1983). Protein in whole cells 
was measured in a Lowry-type reaction (Kennedy \& Fewson 1968). Protein in cell extracts was measured by the method of Bradford (1976).

The eluents for FPLC contained dithiothreitol and were sparged with He. A blank elution purged the system of oxygen. Proteins in a 2-ml portion of processed cell extract (see below) were separated on the anion exchanger equilibrated with eluent $\mathrm{A}$ ( $25 \mathrm{mM}$ potassium phosphate and $2 \mathrm{mM}$ dithiothreitol, $\mathrm{pH} 7.4$ ) at $4 \mathrm{ml} / \mathrm{min}$. Proteins were eluted isocratically for $10 \mathrm{~min}$, when a linear gradient of eluent $\mathrm{B}$ (eluent A containing $1 \mathrm{M} \mathrm{Na}_{2} \mathrm{SO}_{4}$ ) to $15 \%$ $B$ over 42 min was started; thereafter, the flow rate was reduced to $2.5 \mathrm{ml} / \mathrm{min}$ and the gradient was ramped to $100 \% \mathrm{~B}$ over $13 \mathrm{~min}$, after which the initial conditions were regenerated. 20 -ml fractions were collected anaerobically and examined immediately.

Gradient separations by HPLC were done on reversed-phase columns (Grossenbacher et al. 1986) at a flow rate of $1 \mathrm{ml} / \mathrm{min}$ with $20-\mu \mathrm{l}$ or $3-\mathrm{ml}$ samples, and $1-\mathrm{ml}$ fractions were collected. UV detection $(205 \mathrm{~nm}$ ) was used. The initial eluent, C, was $100 \mathrm{mM}$-potassium phosphate buffer, $\mathrm{pH} 4.0$; the second eluent, $\mathrm{D}$, was $80 \%(\mathrm{v} / \mathrm{v})$ methanol in $10 \mathrm{mM}$-potassium phosphate buffer, $\mathrm{pH} 4.0$. Eluent $\mathrm{C}$ was pumped for $5 \mathrm{~min}$, when a linear gradient to $10 \%$ D over $15 \mathrm{~min}$ was applied followed by a linear gradient to $100 \% \mathrm{D}$ over $25 \mathrm{~min}$; after one min, the initial conditions were regenerated. The separated fractions were then brought to pH 7.4. When products from dechlorination of ${ }^{14} \mathrm{CCl}_{4}$ by aquocobalamin were examined, portions of fractions were examined for radioactivity.

\section{Organism and growth media}

Acetobacterium woodii DSM 1030 was obtained from the culture collection (Deutsche Sammlung von Mikroorganismen, Braunschweig, FRG).

$A$. woodii was grown under autotrophic and heterotrophic conditions (Balch et al. 1977). Inocula for experiments were grown under autotrophic conditions. Batches of cells from which extracts were to be made were grown in the dark at $30^{\circ} \mathrm{C}$ in $500-\mathrm{ml}$ portions of fructose $(10 \mathrm{mM})$ medium in $1-1$ bottles under an atmosphere of $\mathrm{N}_{2}$ plus $\mathrm{CO}_{2}(80$ : $20, \mathrm{v} / \mathrm{v}$ ) from an inoculum of $20 \mathrm{ml}$. The cultures were harvested anaerobically in the late exponential phase of growth $\left(5000 \mathrm{~g}, 15 \mathrm{~min}, 4^{\circ} \mathrm{C}\right)$ and washed anaerobically $(60 \mathrm{mM} \mathrm{NaHCO}, 5 \mathrm{mM}$ potassium phosphate, $20 \mathrm{mM} \quad \mathrm{NH}_{4} \mathrm{Cl}, 0.4 \mathrm{mM}$ $\mathrm{MgSO}_{4}, 3 \mathrm{mM} \mathrm{Na} \mathrm{S}_{2}, 2.5 \mathrm{mM}$ L-cysteine- $\mathrm{HCl}$ and $4 \mu \mathrm{M}$ resazurin, $\mathrm{pH} 7.0$ ). All subsequent steps in the experiment were done anaerobically at $0-4^{\circ} \mathrm{C}$ in the dark, unless otherwise stated: fresh cells were used, because alterations in properties were observed if cells were stored. Pellets of $A$. woodii were suspended $(250 \mathrm{mg}$ wet weight $/ \mathrm{ml})$ in extraction buffer $\left(40 \mathrm{mM}\right.$ Tris- $\mathrm{HCl}, 2 \mathrm{mM} \mathrm{NaHCO}{ }_{3}$, $3 \mathrm{mM} \mathrm{Na}_{2} \mathrm{~S}, 2.5 \mathrm{mM}$ L-cysteine-HCl, $1 \mu \mathrm{M}$ phenylmethane sulfonyl fluoride (PMSF) and $4 \mu \mathrm{M}$ resazurin, adjusted to $\mathrm{pH} 7.0$ at room temperature) and ruptured by three passages through a cold French pressure cell at $120 \mathrm{MPa}$. Whole cells and debris were removed by centrifugation $(30000 \mathrm{~g}, 60 \mathrm{~min}$, $4^{\circ} \mathrm{C}$ ). The supernatant fluid was treated with protamine sulfate to remove nucleic acids: $20 \%(\mathrm{v} / \mathrm{v})$ of cold $2 \%$ protamine sulfate in eluent buffer $\mathrm{A} / \mathrm{p}$ (buffer A containing 0.1 mM PMSF) was stirred into crude extract over $10 \mathrm{~min}$ at $4^{\circ} \mathrm{C}$, after which the precipitate was removed by centrifugation $\left(30000 \mathrm{~g}, 30 \mathrm{~min}, 4^{\circ} \mathrm{C}\right)$. This supernatant fluid (portions of $2.5 \mathrm{ml}$ ) was first desalted on a PD-10 column to remove molecules of $M_{r}<5000$ (e.g. free vitamin $\mathrm{B}_{12}$ ) and to bring the protein fraction into buffer $\mathrm{A} / \mathrm{p}$. Small molecules from the crude extract were considered to be those in the 5.5$8.5 \mathrm{ml}$ fraction eluted from the PD-10 column.

\section{Conditions for the assays of dechlorination}

The transformation of $\mathrm{CCl}_{4}$ in solutions of aquocobalamin was examined at $30^{\circ} \mathrm{C}$ in $20-\mathrm{ml}$ reaction mixtures contained in $150-\mathrm{ml} \mathrm{screw-cap} \mathrm{bottles} \mathrm{fit-}$ ted with Viton stoppers; the gas phase was a mixture of $\mathrm{N}_{2}$ and $\mathrm{CO}_{2}(80: 20, \mathrm{v} / \mathrm{v})$. The reaction mixture contained $2 \mathrm{mmol}$ potassium phosphate buffer, pH 7.2, $83 \mu \mathrm{mol}$ L-cysteine, $128 \mu \mathrm{mol} \mathrm{Na}_{2} \mathrm{~S}$, $1 \mu \mathrm{mol} \mathrm{CCl}$ (containing $360 \mathrm{MBq}{ }^{14} \mathrm{CCl}_{4}$ ), and, after a preincubation period, 7.4 to $74 \mathrm{nmol}$ aquocobalamin, with which the reaction was started. 
Some experiments were done with 4 mmol titanium (III)-citrate in place of the sulfur-containing reductants. Samples of headspace were taken at intervals for $20 \mathrm{~h}$ and examined for chlorinated solvents, $\mathrm{CO}$ and $\mathrm{CO}_{2}$ (see below). Thereafter, the reaction mixture was acidified, extracted and examined for water-soluble products (see below). In some experiments, the aquocobalamin was replaced by suspensions of native or autoclaved cells of $A$. woodii (4.8 $\mathrm{mg}$ of protein).

The source of the proton in $\mathrm{CHCl}_{3}$ formed from $\mathrm{CCl}_{4}$ was examined in a suspension of cells of $A$. woodii. A. woodii was grown heterotrophically with fructose as the carbon source in medium made up with $\mathrm{H}_{2} \mathrm{O}$ or $\mathrm{D}_{2} \mathrm{O}$. Cells were harvested and washed in buffer prepared in $\mathrm{H}_{2} \mathrm{O}$ and $\mathrm{D}_{2} \mathrm{O}$, respectively. The transformation of $\mathrm{CCl}_{4}$ in suspensions of $A$. woodii was done in $25-\mathrm{ml}$ reaction mixtures contained in $150-\mathrm{ml}$ screw-cap bottles fitted with Viton stoppers; the gas phase was a mixture of either $\mathrm{N}_{2}$ and $\mathrm{CO}_{2}\left(80: 20\right.$, v/v) or $\mathrm{H}_{2}$ and $\mathrm{CO}_{2}(80$ : $20, \mathrm{v} / \mathrm{v})$. The reaction mixture contained $2 \mathrm{mmol}$ potassium phosphate buffer, $\mathrm{pH} 7.2,83 \mu \mathrm{mol} \mathrm{L}-$ cysteine, $128 \mu \mathrm{mol} \mathrm{Na} \mathrm{Na}_{2}, 5 \mu \mathrm{mol} \mathrm{CCl}_{4}$ and $40 \mathrm{mg}$ wet wt of cells, with which the reaction was started after a preincubation period. The reaction was terminated after $9 \mathrm{~h}$ by the addition of $5 \mu \mathrm{mol}$ of $\mathrm{NaOH}$. Samples $(1 \mathrm{ml})$ of headspace were then taken and analyzed by GC coupled to a mass spectrometer. The relative abundance of the fragments of $m / z 83\left({ }^{12} \mathrm{CH}^{35} \mathrm{Cl}_{2}{ }^{+}\right)$and $84\left({ }^{12} \mathrm{CD}^{35} \mathrm{Cl}_{2}^{+}\right)$was used to determine the relative amounts of $\mathrm{CHCl}_{3}$ and $\mathrm{CDCl}_{3}$ formed during the incubation.

The degradation of $\mathrm{CCl}_{4}$ by fractionated proteins from extracts of $A$. woodii was examined at $30^{\circ} \mathrm{C}$ in undiluted $20-\mathrm{ml}$ portions in $125-\mathrm{ml}$ screw-cap bottles closed with Viton stoppers: the gas phase was a mixture of $\mathrm{N}_{2}$ and $\mathrm{CO}_{2}(80: 20, \mathrm{v} / \mathrm{v})$. Extract and $\mathrm{CCl}_{4}(1 \mu \mathrm{mol})$ were incubated for $30 \mathrm{~min}$ to allow equilibration of $\mathrm{CCl}_{4}$ between the gas and aqueous phases, and the reaction was considered to be initiated by the addition of the reductant, titanium (III)-citrate (about $20 \mu \mathrm{mol}$ ); samples of headspace were taken at 0 and $12 \mathrm{~h}$ for analysis by GCFID. Thereafter, samples for determinations of vitamin $\mathrm{B}_{12}, \mathrm{Ni}, \mathrm{Fe}$ and $\mathrm{Co}$ were taken. When fractions were due to be examined after autoclav- ing, each pooled fraction was divided into two equal portions, one of which was autoclaved, and reactions were followed as above.

The degradation of $\mathrm{CCl}_{4}$ by fractionated small molecules from extracts of $A$. woodii was examined at $30^{\circ} \mathrm{C}$ in undiluted $5-\mathrm{ml}$ portions in $125-\mathrm{ml}$ screwcap bottles closed with Viton stoppers: the gas phase was a mixture of $\mathrm{N}_{2}$ and $\mathrm{CO}_{2}(80: 20, \mathrm{v} / \mathrm{v})$. Extract and $\mathrm{CCl}_{4}(1 \mu \mathrm{mol})$ were incubated for 30 min to allow equilibration of $\mathrm{CCl}_{4}$ between the gas and aqueous phases, and the reaction was considered to be initiated by the addition of the reductant, titanium(III)-citrate (about $20 \mu \mathrm{mol}$ ); samples of headspace were taken at 0 and $12 \mathrm{~h}$ for analysis by GC-FID after which samples were taken for the determination of vitamin $B_{12}$.

\section{Results}

Analysis of products from the reaction of A. woodii with $\mathrm{CCl}_{4}$

As anticipated (see Introduction), native cells of $A$. woodii transformed $\mathrm{CCl}_{4}$ to reduced products $\left(\mathrm{CHCl}_{3}\right.$ and $\left.\mathrm{CH}_{2} \mathrm{Cl}_{2}\right), \mathrm{CO}_{2}$, water-soluble non-volatiles and material associated with the cell (Table 1). The amount of reduced products changed and decreased with time, with a corresponding increase in polar non-volatiles. In addition, $\mathrm{CO}$ was observed in the gas phase: it cochromatographed with authentic material (radioactivity) and was converted to $\mathrm{CH}_{4}$ in the methanizer. $\mathrm{CO}$ was detected at levels of about $1 \%$ of the educt, whether measured radiochemically or with the methanizer (Table 1). The recovery of radioactivity from $\mathrm{CCl}_{4}$ was 88 to $99 \%$.

The products formed from $\mathrm{CCl}_{4}$ by autoclaved cells of $A$. woodii differed from the control with native cells in that negligible amounts of $\mathrm{CHCl}_{3}$ remained after $20 \mathrm{~h}$ (Table 1). As with native cells, the autoclaved material catalyzed the formation of $\mathrm{CO}$. The recovery of radioactivity was consistently lower than from experiments with native cells (Table 1).

Cells of $A$. woodii which had been autoclaved in the presence of air were also able to catalyze the 
anaerobic transformation of $\mathrm{CCl}_{4}$. The products, and their rates of formation, were essentially identical with those from cells autoclaved under anaerobic conditions. The rate of dechlorination in native cells could be increased by a factor of 2 to 4 by replacing nitrogen in the gas phase with hydrogen, or by retaining the gas phase of nitrogen plus carbon dioxide and adding fructose.

\section{Reaction products from $\mathrm{CCl}_{4}$ in a solution of aquocobalamin and reducing agents}

The rate of disappearance of $\mathrm{CCl}_{4}$ catalyzed by aquocobalamin was directly proportional to the concentration of aquocobalamin between 7 and $74 \mathrm{nmol} /$ assay, and the turnover was $14 \mathrm{mkat} / \mathrm{mol}$ of aquocobalamin. The fate of radioactivity from ${ }^{14} \mathrm{CCl}_{4}$ in anaerobic solutions of aquocobalamin was examined. The yield of reduced products was low, and most of the products consisted of nonvolatile, water-soluble material, $\mathrm{CO}$ and $\mathrm{CO}_{2}$ (Table 1). The non-volatile material was separated by gradient elution from a reversed-phase HPLC column in four distinct peaks $\left(\mathrm{T}_{\mathrm{r}}\right.$ 4.0, 7.5, 19 and $34 \mathrm{~min}$ ). The fourth peak eluted shortly after aquo- cobalamin $\left(T_{\mathrm{r}} 24 \mathrm{~min}\right)$. It was red when the material was concentrated, and had a UV spectrum resembling that of aquocobalamin (e.g., $\lambda_{\max }$ values close to 278,361 and $551 \mathrm{~nm}$ ). We presume this to be derivatized aquocobalamin.

The transformations of $\mathrm{CCl}_{4}$ by native aquocobalamin (Table 1) were also observed with autoclaved aquocobalamin. The range of products was altered very little, but the specific rate of transformation was increased by about $30 \%$. Aquocobalamin was also autoclaved in an atmosphere of air and tested for its ability to transform $\mathrm{CCl}_{4}$ anaerobically. The cofactor was active, with relatively small changes in the distribution of products formed, and the rate was some $50 \%$ higher than in the control.

The range of reactions catalyzed by aquocobalamin is wider than previously recognized (see Introduction). Qualitative comparisons in Table 1 show that the same range of products is formed by $A$. woodii and by aquocobalamin. It is thus possible to hypothesize that cellular vitamin $\mathrm{B}_{12}$, an analogue of aquocobalamin, could be responsible for all the reactions with $\mathrm{CCl}_{4}$ that are catalyzed by the organism in vivo.

Table 1. Products formed from $\mathrm{CCl}_{4}$ in the presence of reducing agents in suspensions of native or autoclaved cells of $A$. woodii and in solutions of aquocobalamina.

\begin{tabular}{|c|c|c|c|c|c|c|}
\hline \multirow[t]{2}{*}{ Compound } & \multicolumn{6}{|c|}{$\begin{array}{l}\text { Amount of product ( } \% \text { of initial amount of } \mathrm{CCl}_{4} \text { ) present after the given incubation period in the presence of: } \\
\text { native cells } \\
\text { autoclaved cells }\end{array}$} \\
\hline & $4.5 \mathrm{~h}$ & $20 \mathrm{~h}$ & $4.5 \mathrm{~h}$ & $20 \mathrm{~h}$ & $15 \mathrm{nmol}, 20 \mathrm{~h}$ & $74 \mathrm{nmol}, 20 \mathrm{~h}$ \\
\hline $\mathrm{CCl}_{4}$ & 0 & 0 & 0 & 5 & 0 & 0 \\
\hline $\mathrm{CHCl}_{3}$ & 47 & 3 & 26 & $<0.5$ & 0 & 1 \\
\hline $\mathrm{CH}_{2} \mathrm{Cl}_{2}$ & 6 & 17 & 9 & $<0.5$ & 10 & 1 \\
\hline $\mathrm{CO}_{2}$ & 6 & 8 & 4 & 9 & 8 & 29 \\
\hline $\mathrm{CO}$ & nd & 1 & nd & 2 & 15 & 10 \\
\hline Polar non-volatiles & 34 & 50 & 36 & 52 & 49 & 54 \\
\hline Associated with cells & 6 & 6 & 5 & 9 & - & - \\
\hline Mass balance & 99 & 85 & 80 & 78 & 82 & 95 \\
\hline
\end{tabular}

\footnotetext{
${ }^{a}$ About $1000 \mathrm{nmol}$ of $\mathrm{CCl}_{4}$ was incubated in phosphate buffer with aquocobalamin or native or autoclaved cells of $A$. woodii, and each reaction mixture was reduced with $\mathrm{H}_{2} \mathrm{~S}$ and $\mathrm{L}$-cysteine- $\mathrm{HCl}$. Most of the data were obtained radiochemically, but $\mathrm{CO}$ was quantified in a methanizer in an experiment with ${ }^{12} \mathrm{CCl}_{4}$. $\mathrm{CO}_{2}$ from $\mathrm{CCl}_{4}$ could also be detected in the methanizer if the system was scrupulously free of exogenous $\mathrm{CO}_{2}$. Similar products were observed when the system was reduced with titanium(III) citrate in place of $\mathrm{H}_{2} \mathrm{~S}$ and L-cysteine-HCl. Data from representative experiments are shown, but each experiment was done in duplicate at least twice, where appropriate with independently-grown cells.
} 


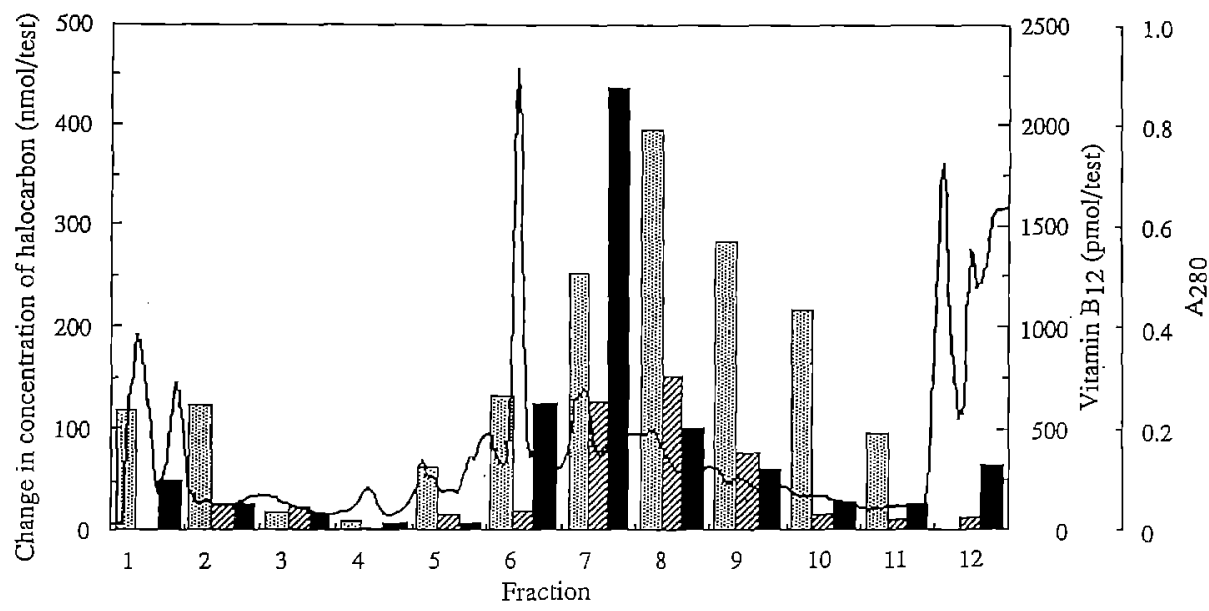

Fig. 1. Separation of proteins from desalted extract of $A$. woodii, and the dechlorinative activities of the resulting fractions. The eluate from the anion-exchange column was divided into twelve 5 -min fractions which were examined for dechlorinative activity under native conditions and for vitamin $\mathbf{B}_{12}$, as detailed in the Methods section. - - $\mathrm{A}_{280}$; 国, disappearance of $\mathrm{CCl}_{4}$;, formation of $\mathrm{CHCl}_{3}$; $\mathbf{\square}$, vitamin $\mathbf{B}_{12}$.

Transformation of $\mathrm{CCl}_{4}$ by protein fractions from A. woodii

Desalted soluble proteins from $A$. woodii were separated by ion-exchange chromatography (Fig. 1). Dechlorinative activity (disappearance of $\mathrm{CCl}_{4}$ ) was routinely observed in many fractions, whereas others (3, 4 and 12) had negligible activity. The proportion of the reductive reaction (measured as formation of $\mathrm{CHCl}_{3}$ ) varied from undetectable (fraction 1) to $50 \%$ (fraction 7 ): no attempt was made to define the other reaction products (cf. Table 1). We presume that both reductive and substitutive reactions were catalyzed by native fractions, but the reaction rate correlated very poorly with the levels of vitamin $B_{12}$ observed in the fractions. The relative activity attributed to vitamin $B_{12}$ varied widely ( 8 and $0.5 \mathrm{mkat} / \mathrm{mol}$ for fractions 7 and 10 , respectively).

In experiments similar to that in Fig. 1, dechlorination of $\mathrm{CCl}_{4}$ in native separated proteins and in autoclaved material were compared (Fig. 2). A major alteration in the pattern of dechlorination was caused by autoclaving. In general there was a decreased discrepancy between specific activities of dechlorination (calculated per mol vitamin $\mathrm{B}_{12}$ ) and levels of vitamin $B_{12}$ in autoclaved extracts, compared with native enzymes. Further, some samples now dechlorinated although little or no vitamin $B_{12}$ was present (fractions 8 and 11). We attempted to correlate the levels of iron, nickel and cobalt with dechlorination (not shown), but there was no direct relationship between dechlorination and the presence of these ions.

Transformation of $\mathrm{CCl}_{4}$ by fractioned small molecules from A. woodii

The small molecules in cell extracts of $A$. woodii were separated on a reversed phase column (Fig. 3). There was dechlorination in at least five of the ten blocks of fractions. One of the least active was fraction 7 , in which the vitamin $B_{12}$ eluted. The catalytic activity calculated for sample 7 is, however, $6 \mathrm{mkat} / \mathrm{mol}$ of vitamin $B_{12}$, similar to that of aquocobalamin (14 mkat/mol), so vitamin $B_{12}$ separated from growing cells behaves normally in our dechlorinative test in vitro. At least four fractions catalyzed dechlorination in the absence of vitamin $B_{12}$. The organism must, therefore, contain other (co)factors that are able to catalyze dechlorination. 


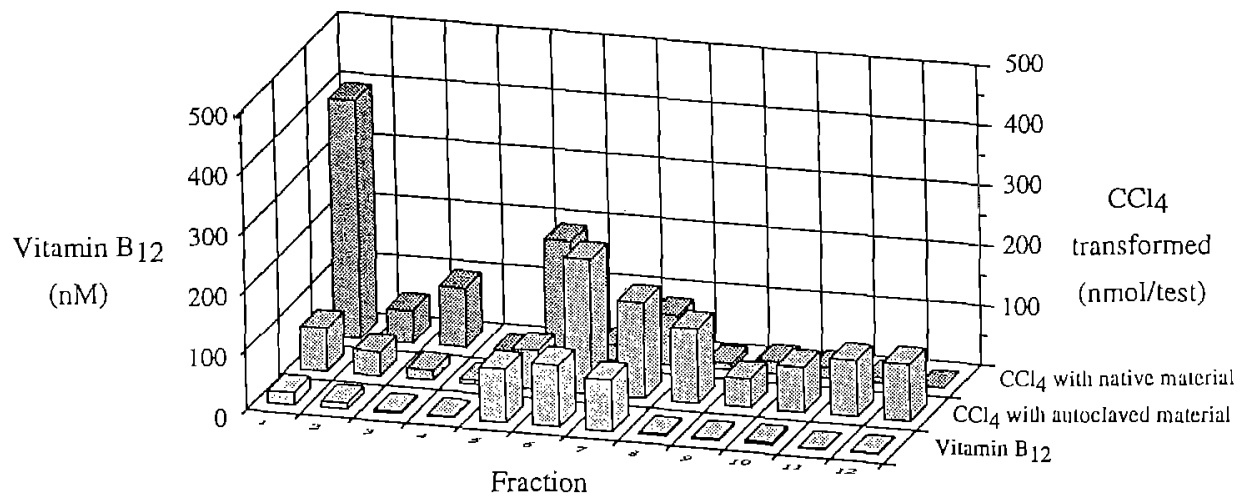

Fig. 2. Correlation of vitamin $\mathrm{B}_{12}$ and disappearance of $\mathrm{CCl}_{4}$ catalyzed by native and autoclaved fractions from the chromatographic separation of native proteins of $A$. woodii. A separation of native proteins of $A$. woodii was done, analogous to that in Fig. 1 . Each fraction was split in two, one of which was autoclaved. The disappearance of $\mathbf{C C l}_{4}$ from reaction mixtures containing native and autoclaved material was examined, as was the content of vitamin $B_{12}$. This is a typical experiment, as is Fig. 1, and both were done under identical chromatographic conditions. The block of fractions containing most vitamin $B_{12}(5,6$ and 7$)$ eluted earlier than the same material in Fig. 1 (fractions 6, 7 and 8). The general pattern, however, was consistent.

The nature of $\mathrm{CHCl}_{3}$ formed from $\mathrm{CCl}_{4}$ by

A. woodii

Cells grown in medium based on $\mathrm{H}_{2} \mathrm{O}$ and incubated in a reaction mixture based on $\mathrm{H}_{2} \mathrm{O}$ produced only protochloroform from $\mathrm{CCl}_{4}$ (Table 2 ). When $\mathrm{D}_{2} \mathrm{O}$ was used in the reaction mixture, the product was largely deuterochloroform, whether the cells derived from growth medium prepared in $\mathrm{H}_{2} \mathrm{O}$ or $\mathrm{D}_{2} \mathrm{O}$. The presence of $\mathrm{H}_{2}$ in the gas phase of the reaction mixture had little effect on the relative amount of deuterochloroform produced.

\section{Discussion}

We have confirmed and extended our earlier work to show that native cells of $A$. woodii quantitatively convert ${ }^{14} \mathrm{CCl}_{4}$ not only to $\mathrm{C}-1$ compounds $\left(\mathrm{CHCl}_{3}\right.$, $\mathrm{CH}_{2} \mathrm{Cl}_{2}, \mathrm{CO}$ and $\mathrm{CO}_{2}$ ) but also to non-volatile, water-soluble compounds and to material firmly bound to cells (Table 1); there is high to complete recovery of the labelled carbon. In contrast to earlier work with tetrapyrrole cofactors (see Introduction) we observe a complete mass balance for the degradation of $\mathrm{CCl}_{4}$ by aquocobalamin (Table 1). Our use of ${ }^{14} \mathrm{CCl}_{4}$ allowed us to trace the products, $\mathrm{CHCl}_{3}, \mathrm{CH}_{2} \mathrm{Cl}_{2}, \mathrm{CO}$ and $\mathrm{CO}_{2}$, and non-volatile, water-soluble compounds. So aquocobalamin does indeed catalyze a set of reactions analogous to those in native cells of $A$. woodii (cf. Introduction).

Our data with aquocobalamin confirm and extend those of Krone et al. (1989b, 1991). Stromeyer (unpublished) reproduced the core data of Krone et al. (1991), but we chose to work with phosphate buffer at physiological $\mathrm{pH}$, to reproduce conditions in the growth medium. Krone et al. (1989a, b, 1991) detected solely those volatile compounds with a low background by $\mathrm{GC}$-(methanizer)-FID $\left(\mathrm{CHCl}_{3}\right.$, $\mathrm{CH}_{2} \mathrm{Cl}_{2}, \mathrm{CH}_{3} \mathrm{Cl}$ and $\mathrm{CO}$ ), the absence of significant amounts of formate and the very incomplete mass balance for carbon (50 to $70 \%$ ). Our detection of $\mathrm{CO}_{2}$ and the four separable, water-soluble products completes the mass balance for carbon. There is no mass balance for chlorine, which reflects the difficulty of measuring chloride ion accurately by colourimetric methods in samples containing reducing agents.

Krone et al. (1991) attributed our observation of $\mathrm{CO}_{2}$ production (Egli et al. 1988, 1990) to the action of $\mathrm{CO}$ dehydrogenase on $\mathrm{CO}$ produced by e.g., vitamin $B_{12}$. The assumption may be largely true in growing cells (Egli et al. 1988), but it is unlikely in autoclaved cells (Table 1; Egli et al. 1990). Indeed, $\mathrm{CO}_{2}$ is formed from $\mathrm{CCl}_{4}$ in organisms without the acetyl-CoA pathway, Escherichia coli and Pseudomonas sp., in which some or 


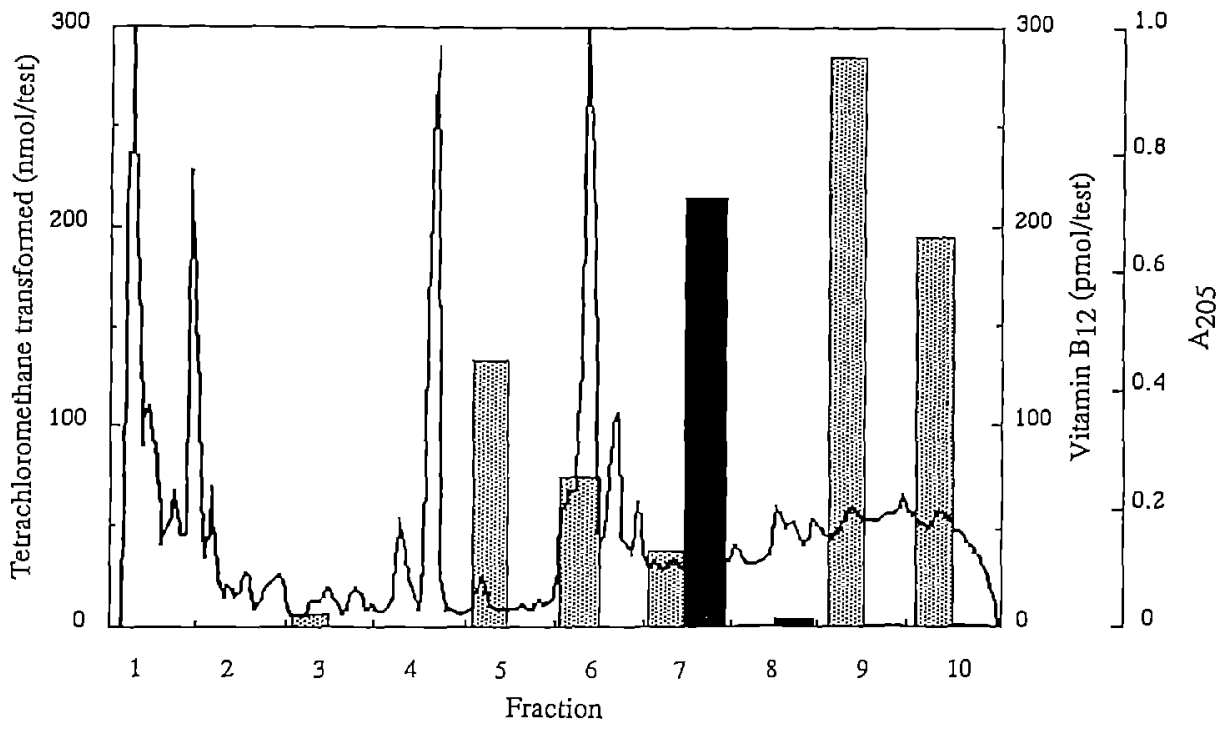

Fig. 3. Separation of small molecules from crude extract of $A$. woodii, and the dechlorinative activities of the resulting fractions. Small molecules $\left(M_{r}<5000\right)$ from crude extract of $A$. woodii were separated on a reversed-phase column, as described in the Methods section. These fractions were examined for dechlorinative activity and for vitamin $B_{12}$. $\mathrm{CCl}_{4}$; ; vitamin $\mathrm{B}_{12}$. The $\mathrm{GC}$-assay for disappearance of $\mathrm{CCl}_{4}$ was straightforwatd in the early fractions, but with increasing amounts of methanol, the $\mathrm{CCl}_{4}$-peak was located on the 'tail' of the methanol peak, and could be measured with only reduced accuracy. In blank runs we confirmed that eluent from the column did not cause disappearance of $\mathrm{CCl}_{4}$.

all of the products in Table 1 are formed (Criddle et al. $1990 \mathrm{a}, \mathrm{b})$.

A major argument for tetrapyrroles as the nonenzymic catalysts is their heat stability (Fridrich 1975). The heat stability of the whole range of reactions involved in dechlorination by whole cells (Table 1) and aquocobalamin (see text) is reconfirmed in this work. If any activity is curtailed by autoclaving, it is the reductive reaction (cf. Egli et al. 1990), but the high levels of reduced intermediates at $4.5 \mathrm{~h}$ in the autoclaved cells compared with the low residual levels of reduced intermediates $(20 \mathrm{~h})$ may actually indicate that the reductive reaction is faster or more complete or altered under these conditions. The repeatedly low recovery of carbon from autoclaved cells (Table 1; Egli et al. 1990) leads us to suspect the formation of as yet unidentified volatile products under these conditions.

We found free vitamin $B_{12}$ from $A$. woodii to have a specific activity for dechlorination $(6 \mathrm{mkat} /$ mol; Fig. 3) similar to that of aquocobalamin (14 $\mathrm{mkat} / \mathrm{mol}$ ) in our system, which was chosen to represent simplified growth medium for the organism.
The protein-bound vitamin $B_{12}$ had a maximum specific activity in the same order of magnitude (about $8 \mathrm{mkat} / \mathrm{mol}$ in fraction 7 in Fig. 1) and a minimum of about $0.5 \mathrm{mkat} / \mathrm{mol}$ (fraction $10 \mathrm{in} \mathrm{Fig.}$ 1). We presume that this range of dechlorinative

Table 2. The source of protons in chloroform from $\mathrm{CCl}_{4}$ in reactions catalyzed by whole cells of $A$. woodii in the presence of $\mathrm{H}_{2} \mathrm{O}$ or $\mathrm{D}_{2} \mathrm{O}$.

\begin{tabular}{|c|c|c|c|}
\hline \multicolumn{2}{|c|}{ Incubation conditions } & \multicolumn{2}{|c|}{ Distribution (\%) of products } \\
\hline & & $\mathrm{CHCl}_{3}$ & $\mathrm{CDCl}_{3}$ \\
\hline \multicolumn{4}{|c|}{ Cells grown in $\mathrm{H}_{2} \mathrm{O}$} \\
\hline Reaction buffer & $\mathrm{H}_{2} \mathrm{O}$ & & \\
\hline Gas phase & $\mathrm{N}_{2}+\mathrm{CO}_{2}$ & $>99.5$ & $<0.5$ \\
\hline Reaction buffer & $\mathrm{D}_{2} \mathrm{O}$ & & \\
\hline Gas phase & $\mathrm{N}_{2}+\mathrm{CO}_{2}$ & $<0.5$ & $>99.5$ \\
\hline \multicolumn{4}{|c|}{ Cells grown in $\mathrm{D}_{2} \mathrm{O}$} \\
\hline Reaction buffer & $\mathrm{D}_{2} \mathrm{O}$ & & \\
\hline Gas phase & $\mathrm{N}_{2}+\mathrm{CO}_{2}$ & 6 & 94 \\
\hline Reaction buffer & $\mathrm{D}_{2} \mathrm{O}$ & & \\
\hline Gas phase & $\mathrm{H}_{2}+\mathrm{CO}_{2}$ & 9 & 91 \\
\hline
\end{tabular}


activities observed for vitamin $B_{12}$ bound to proteins reflects different molecular environments of the cofactor (cf. Dangel et al. 1987). Indeed, some of the very broad peaks we observe in Fig. 1 may represent degradation products from native enzymes, because this column routinely gives much sharper protein bands (Locher et al. 1991). When the dechlorinative activity of cellular vitamin $B_{12}$ depends on its molecular environment, it becomes almost impossible to predict the dechlorinative potential of that vitamin $\mathrm{B}_{12}$ in the organism, even if, as with $A$. woodii, only one known tetrapyrrole is involved. Correspondingly, it is almost impossible to test quantitatively the hypothesis that vitamin $\mathrm{B}_{12}$ is the sole factor responsible for dechlorination in $A$. woodii. In preliminary calculations with data from methanogens, Stumpf (1990) concluded that there was no correlation between dechlorinative activity and published levels of cobalt corrinoids.

The poor correlation of amounts of vitamin $B_{12}$ and the level of dechlorination in native separated proteins (Fig. 1) was repeated in an independent experiment (Fig. 2): the correlation was somewhat improved in that portion of the experiment in which the separated material was autoclaved prior to analysis of dechlorination. Further inconsistencies (dechlorination in fractions 8,11 and 12 in the absence of vitamin $B_{12}$ ), however, indicate that other dechlorinative factors may also be present. This supposition was confirmed when we examined components of low molecular weight from the organism (Fig. 3). This material represented about $50 \%$ of the dechlorinative activity in cell extracts and only a small portion of the dechlorination is attributable to vitamin $B_{12}$. At least four other unidentified fractions are involved. It is thus clear that, however much vitamin $\mathrm{B}_{12}$ contributes to dechlorination in $A$. woodii, other factors in the cell can also dechlorinate $\mathrm{CCl}_{4}$, though here also we do not know what contribution they make to activity in vivo. The detection of small molecules other than vitamin $\mathrm{B}_{12}$ that dechlorinate $\mathrm{CCl}_{4}$ is not surprizing. On the one hand, several metallo-tetrapyrrole-containing systems, besides vitamin $B_{12}$, are known to catalyze dechlorination, though none is known to be present in $A$. woodii (see Introduction). On the other hand, Criddle et al. (1990a, 1990b) have confirmed and extended their older observation (Bouwer \& McCarty 1983) of dechlorination by organisms lacking the acetyl-CoA pathway (and the corresponding corrinoids), so there must be other dechlorinative factors such as the flavins postulated in the introduction.

The reductive reaction with $\mathrm{CCl}_{4}$ has been known for a considerable time, firstly in mixed cultures and more recently in pure cultures (Cook et al. 1988; Vogel et al. 1987), but we present the first evidence to show that the proton involved is derived from water (Table 2) rather than from e.g., cellular protons or molecular hydrogen. Our data contrast with results from liver microsomes, where the proton was derived not from water or hydrogen but from cellular protons (Ahr et al. 1980). It is unclear whether water itself is involved in the reaction or whether a proton from water, as proposed by Krone et al. (1991). However this is resolved, one basis of the dechlorinations with the cobalt corrinoid is a series of radical reactions (Krone et al. 1989a, b, 1991). Up till now, only a portion of the products was recognized $\left(\mathrm{CHCl}_{3}, \mathrm{CH}_{2} \mathrm{Cl}_{2}, \mathrm{CO}\right.$, $\mathrm{CO}_{2}$ ). We interpret the radioactivity from ${ }^{14} \mathrm{CCl}_{4}$ in a molecule with a similar UV-visible spectrum to, but lower polarity than, vitamin $B_{12}$ to be a chloromethyl derivative of aquocobalamin, caused by a chloromethyl radical being quenched on a molecule of the corrinoid. Similarly, the other materials in the chromatogram could also represent quenched radicals. Correspondingly, the radioactivity in cell material (Table 1) would represent radicals which were quenched on cellular structures.

The complete disappearance of $\mathrm{CCl}_{4}$ in the presence of aquocobalamin, $A$. woodii or methanogens (Krone et al. 1989b) thus does not represent complete degradation but transformation by a nonenzymic catalyst to largely unidentified, but probably chlorinated, products. It is also difficult to see what the organism gains from the reaction. It may be a detoxicative reaction, where the cost of derivatizing cell components is a lower risk than the halocarbon. The reaction was probably not selected for by evolution, being the side reaction of a cofactor, rather than an enzymic reaction. The reaction in native cells can be accelerated by providing reducing equivalents (from $\mathrm{H}_{2}$ or fructose) but 
it seems unlikely that the cell will be able to harvest any physiological gain from e.g., the reduction of $\mathrm{CCl}_{4}$, because this electron sink is apparently not coupled to an electron transport chain.

The non-directed nature of the biotransformation of $\mathrm{CCl}_{4}$, discussed above, differs markedly from the utilization of haloaliphatic compounds as carbon and energy sources under anaerobic conditions. In the latter cases, there is complete mass balance for carbon and chlorine (Egli et al. 1989; Stromeyer et al. 1991; Freedman \& Gossett 1991; Traunecker et al. 1991). The reactions are enzymecatalyzed and, where known, involve a defined degradative pathway.

\section{Acknowledgements}

We are grateful to Prof. B. Kräutler for stimulating discussions. We thank Rudi Schläfli for support using HPLC and FPLC, and Andreas Dutly, Technische Chemie, ETH, for the GC-MS analyses. K. Barmettler, Terrestrische Oekologie, ETH, kindly made AAS available. Experiments with radiocobalt were done in the laboratories of Labormed AG, Zürich. The work was supported by a grant from the Swiss Federal Institute of Technology, Zürich, and by IBL Umwelt- und Biotechnik, Heidelberg.

\section{References}

Ahr HJ, King LJ, Nastainczyk W \& Ullrich V (1980) The mechanism of chloroform and carbon monoxide formation from carbon tetrachloride by microsomal cytochrome P-450. Biochem. Pharmacol. 29: 2855-2861

Balch WE, Fox GE, Magrum LJ, Woese CR \& Wolfe RS (1979) Methanogens: reevaluation of a unique biological group. Microbiol. Rev. 43: 260-296

Balch WE, Schoberth S, Tanner RS \& Wolfe RS (1977) Acetobacterium, a new genus of hydrogen-oxidizing, carbon dioxide-reducing, anaerobic bacteria. Int. J. Syst. Bacteriol. 27: 355-361

Bouwer EJ \& McCarty PL (1983) Transformations of halogenated organic compounds under denitrification conditions. Appl. Environ. Microbiol. 45: 1295-1299

Bradford M (1976) A rapid and sensitive method for the quanti- tation of microgram amounts of protein utilizing the principle of protein-dye binding. Anal. Biochem. 72: 248-254

Cook AM, Scholtz R \& Leisinger T (1988) Mikrobieller Abbau von halogenierten aliphatischen Verbindungen. GWF Gas Wasserfach: Wasser Abwasser, 129: 61-69

Criddle CS, DeWitt JT, Grbic-Galic D \& McCarty PL (1990a) Transformation of carbon tetrachloride by Pseudomonas sp. strain KC under denitrifying conditions. Appl. Environ. Microbiol. 56: 3240-3246

Criddle CS, DeWitt JT \& McCarty PL (1990b) Reductive dehalogenation of carbon tetrachloride by Escherichia coli K-12. Appl. Environ. Microbiol. 56: 3247-3254

Dangel W, Schulz H, Diekert G, König H \& Fuchs G (1987) Occurrence of corrinoid-containing membrane proteins in anaerobic bacteria. Arch. Microbiol. 148: 52-56

Egli C, Scholtz R, Cook AM \& Leisinger T (1987) Anaerobic dechlorination of tetrachloromethane and 1,2-dichloroethane to degradable products by pure cultures of Desulfobacterium sp. and Methanobacterium sp. FEMS Microbiol. Lett. 43: 257-261

Egli C, Stromeyer S, Cook AM \& Leisinger T (1990) Transformation of tetra- and trichloromethane to $\mathrm{CO}_{2}$ by anaerobic bacteria is a non-enzymic process. FEMS Microbiol Lett. 68: 207-212

Egli C, Thüer M, Suter D, Cook AM \& Leisinger T (1989) Mono- and dichloroacetic acids as carbon and energy sources for a stable, methanogenic mixed culture. Arch. Microbiol. 152: 218-223

Egli C, Tschan T, Scholtz R, Cook AM \& Leisinger T (1988) Transformation of tetrachloromethane to dichloromethane and carbon dioxide by Acetobacterium woodii. Appl. Environ. Microbiol. 54: 2819-2824

Fridrich W (1975) Vitamin $B_{12}$ und verwandte Corrinoide. Georg Thieme Verlag, Stuttgart

Freedman DL \& Gossett JM (1991) Biodegradation of dichloromethane and its utilization as a growth substrate under methanogenic conditions. Appl. Environ. Microbiol. 57: 28472857

Fuchs G, Stupperich E \& Eden G (1980) Autotrophic $\mathrm{CO}_{2}$ fixation in Chlorobium limicola. Evidence for the operation of a reductive tricarboxylic acid cycle in growing cells. Arch. Microbiol. 128: 64-71

Gälli R \& McCarty PL (1989) Biotransformation of 1,1,1-trichloroethane, trichloromethane, and tetrachloromethane by a Clostridium sp. Appl. Environ. Microbiol. 55: 837-844

Gantzer CJ \& Wackett PL (1991) Reductive dechlorination catalyzed by bacterial transition-metal coenzymes. Environ. Sci. Technol. 25: 715-722

Grossenbacher H, Thurnheer T, Zürrer D \& Cook AM (1986) Determination of sulfonated azo dyestuffs and their bacterial metabolites by high pressure liquid chromatography. J. Chromatogr. 360: 219-223

Holliger C, Schraa G, Stams AJM \& Zehnder AJB (1990) Reductive dechlorination of 1,2-dichlorocthane and chloroethane by cell suspensions of methanogenic bacteria. Biodegradation 1: 253-261 
Kennedy SIT \& Fewson CA (1968) Enzymes of the mandelate pathway in bacterium N.C.I.B. 8250. Biochem. J. 107: 497506

Kiener A \& Leisinger T (1983) Oxygen sensitivity of methanogenic bacteria. Syst. Appl. Microbiol. 4: 305-312

Klecka GM \& Gonsior SJ (1984) Reductive dechlorination of chlorinated methanes and ethanes by reduced iron(II) porphyrins. Chemosphere 13: 391-402

Krone UE, Laufer K, Thauer RK \& Hogenkamp HPC (1989a) Coenzyme $F_{430}$ as a possible catalyst for the reductive dehalogenation of chlorinated $\mathrm{C}_{1}$-hydrocarbons in methanogenic bacteria. Biochemistry 28: 10061-10065

Krone UE, Thauer RK \& Hogenkamp HPC (1989b) Reductive dehalogenation of chlorinated $\mathrm{C}_{1}$-hydrocarbons mediated by corrinoids. Biochemistry 28: 4908-4914

Krone UE, Thauer RK, Hogenkamp HPC \& Steinbach K (1991) Reductive formation of carbon monoxide from $\mathrm{CCl}_{4}$ and FREONS 11, 12, and 13 catalyzed by corrinoids. Biochemistry 30: 2713-2719

Kuhn EP \& Suflita JM (1989) Dehalogenation of pesticides by anaerobic microorganisms in soils and groundwater - a review. SSSA Spec. Publ. 22: 111-180

Locher HH, Malli C, Hooper SW, Vorherr T, Leisinger T \& Cook AM (1991) Degradation of $p$-toluic acid ( $p$-toluene carboxylic acid) and $p$-toluene sulphonic acid via oxygenation of the methyl sidechain is initiated by the same set of enzymes in Comamonas testosteroni T-2. J. Gen. Microbiol. 137: 22012208

Luria SE (1960) The bacterial protoplasm: composition and organization. In: Gunsalus IC \& Stanier RY (Eds.), The Bacteria, vol 1. (pp 1-34). Academic Press, New York

Scholtz R, Schmuckle A, Cook AM \& Leisinger T (1987) Degradation of eighteen 1-monohaloalkanes by Arthrobacter sp. strain HA1. J. Gen. Microbiol. 133: 267-274

Stromeyer SA, Winkelbauer W, Kohler H, Cook AM \& Leisinger T (1991) Dichloromethane utilized by an anaerobic mixed culture: acetogenesis and methanogenesis. Biodegradation 2: 129-137

Stumpf K (1990) Reduktive und substitutive Dechlorierung von $\mathrm{CCl}_{4}$ bei Anaerobiern. Semesterarbeit, ETH-Zürich

Stupperich E, Eisinger HJ \& Kräutler B (1988) Diversity of corrinoids in acetogenic bacteria: $p$-cresolylcobalamide from Sporomusa ovata, 5-methoxy-6-methylbenzimidazolylcobamide from Clostridium formicoaceticum and vitamin $\mathrm{B}_{12}$ from Acetobacterium woodii. Eur. J. Biochem. 172: 459-464

Stupperich E \& Kräutler B (1988) Pseudo vitamin $B_{12}$ or 5hydroxybenzimidazolylcobamide are the corrinoids found in methanogenic bacteria. Arch. Microbiol. 149: 268-271

Traunecker J, PreuB A \& Diekert G (1991) Isolation and characterization of a methyl chloride utilizing, strictly anaerobic bacterium. Arch. Microbiol. 156: 416-421

Vogel TM, Criddle CS \& McCarty PL (1987) Transformations of halogenated aliphatic compounds. Environ. Sci. Technol. 21: 722-736

Wackett PL (1991) Dehalogenation reactions catalyzed by bacteria. In: Martin AM (Ed), Biological Degradation of Waste (pp 187-203). Elsevier, Essex

Welz B (1983) Atomabsorptionsspektrometrie, 3rd Ed. Verlag Chemie, Weinheim 